\title{
How Long Can Neoliberalism Withstand Climate Crisis?
}

\section{JULIUS ALEXANDER MCGEE AND PATRICK TRENT GREINER}

The climate crisis is proving to be antithetical to the neoliberal machines that define current forms of social organization. On the one hand, reducing fossil fuel consumption, the largest contributor to climate change, requires collaborative efforts. These efforts must take into consideration the foundational role of fossil fuels in modern economies. We must acknowledge, for instance, that most peoples' livelihoods are tethered to fossil fuels, which recent studies have demonstrated is not the result of random historical development but deliberate policy. ${ }^{1}$ Fossil fuels continue to be used as a form of social domination - a means to expropriate productive and reproductive labor. In the meantime, renewable sources of energy have become a favored climate-conscious alternative to fossil fuels. Yet, renewables lack many of the characteristics that have made fossil fuels so desirable in production processes, limiting their ability to expropriate human labor. Renewables do not lend themselves to centrally located reserves or the formalized distribution patterns that allow firms to profit from the extraction, production, and consumption of energy, as fossil fuels do. At the same time, climate catastrophes, such as wildfires and hurricanes, disrupt the infrastructural momentum of fossil fuel economies, destabilizing the mechanisms of capital accumulation that derive from the production and consumption of these fuels. We see both of these problems coming to a head in the recent crises unfolding in Chile and California.

In the context of the recent Chilean protests and electricity blackouts across the state of California, it is worth reflecting on the ever-growing and increasingly apparent connections between neoliberalism and climate crisis. The people in Chile protested the widespread inequality that neoliberal climate mitigation policies threaten to exacerbate. Specifically, the recent move by the Chilean government to increase electricity rates by 9.2 percent for over seven million households and raise fares for public transit by 3.75 percent, due to expanded renewable energy

Julius AleXander McGee is assistant professor of sociology at Portland State University. Patrick Trent Greiner is assistant professor of sociology at Vanderbilt University. 
consumption, was largely responsible for the protests. Meanwhile, in California, residents braced themselves for yet another round of planned blackouts implemented by private utility companies - a move intended to prevent future fires. These blackouts affected around three million people over the last few months of 2019 and led many Californians to call for the deprivatization of utilities in the state. ${ }^{2}$

These crises have long and complex histories rooted in Chile's U.S.backed coup d'état in 1973, which established a junta and ousted the democratically elected socialist leader Salvador Allende. The coup opened the door for a neoliberal experiment on electricity markets, the results of which have taken hold in Chile, California, and around the world, and are largely responsible for current electrical power-related crises. It is precisely neoliberalism's legacy that resulted in the propagation of the wholesale energy market systems wreaking havoc in California and Chile. What is more, the social disruption borne from the institution of these complex market structures has been made more acute due to corporate and political reliance on similar approaches to managing the fallout of climate change.

Wholesale energy trading began as an experiment in Chile during the 1980s. Prior to the coup, the Allende-led administration had nationalized its copper industry and utilities as part of an organized effort to transition peacefully to socialism. Following the coup, a new military dictatorship headed by Augusto Pinochet began to reprivatize the recently nationalized markets, an effort that included allowing ExxonMobil to buy copper mines from the government. ${ }^{3}$ As is true for many of Chile's social and economic policy strategies during Pinochet's seventeen years of brutal dictatorship, the junta relied on the guidance of Chicago School economists when it came to reprivatizing energy. This meeting of the minds ultimately led Chile to design a system of energy trading that allowed electricity producers to speculate on future electricity demand and, thereby, to profit from changes in electricity prices. The newly established economic structure, an institution commonly referred to as a wholesale energy trading market, was intended as a way to profit from electricity distribution without increasing the retail price paid by consumers and at first appeared to do so. After the introduction of wholesale trading in Chile, the model quickly spread across the world.

According to its proponents, the wholesale energy market in Chile had the benefit of separating the business of energy production from the business of distributing energy to the public. It was believed that this separation would benefit end users and improve the efficiency of energy systems by inducing competition between firms. Despite this 
tagline, the faults in Chile's wholesale energy market are now visible to all. One of the most glaring fissures is manifesting itself in the ongoing struggle to introduce renewable sources of energy without increasing the cost of electricity to households. Ironically, it was claimed that wholesale energy markets were created to prevent this very situation from arising. The people in Chile protested in response to this tension, as costs of public transit and electricity, which have widened the already high levels of inequality, were in the works. ${ }^{4}$

In the eyes of energy producers around the world, Chile's Atacama Desert is one of the largest solar energy reserves available to humankind - a value derived from the region's dry climate and extreme insolation. In early 2019, Spain's Solarpack Corp. Tecnologica won the auction to produce 123 megawatts of solar energy in Chile. The company has already started installing solar panels in the area and is now positioned to generate the most cost-efficient electricity in the world. ${ }^{5}$ This massive spike in renewable energy production is set to increase the percentage of renewable energy consumed in Chilean households and to make Santiago's subway system one of the first in the world to source most of its power from renewables. ${ }^{6}$ To cover the cost of these changes without cutting into profits, the Chilean government intended to increase household electricity prices by 9.2 percent and the cost of Santiago's metro system (already one of the most expensive in Latin America) by 3.75 percent by 2021 . These two changes are widely acknowledged as having sparked the resentment that resulted in mass protest across the country. The protests were largely successful and in late October the president of Chile, Sebastián Piñera, signed the Electricity Rates Stabilization Bill to overturn the energy price increases, as well as a bill reversing the metro fare increases, to quell the unrest. ${ }^{7}$ The energy price increase was intended to protect the profitability of the wholesale energy market, which was subject to price fluctuation after the introduction of newer sources of renewable energy and a stronger peso. That is, in classic neoliberal fashion, the state extracted revenue from the people to help stabilize - even increase - the rate of capital accumulation during the transition to renewables.

To its credit, Chile is on a path to have renewables make up 70 percent of its energy by 2050 . However, because storage systems for renewable energy are still lacking, banks are reluctant to invest. Concerns such as these raise questions for investors about how well renewables can compete with fossil fuels on the wholesale stage. Thus, to add more security to wholesale energy trading, Chile sought to increase the cost of consumption. Over the years, the austerity imposed on the subway system in Chile has sparked 
numerous protests as the government continues to rely on efficiency standards determined by economists while ignoring the needs of the people. The system has continually served middle-class communities in an effort to maintain economic efficiency while forcing lower-income earners to rely on private busing systems. Although this has changed somewhat in recent years, as Chile has transitioned to a democracy (in the 1990s, the metro system merged with private buses), the bottom line has continued to emphasize economic efficiency at the expense of the people.

In California, wholesale energy markets came through Assembly Bill 1890 in 1996. Among other things, the bill deregulated energy monopolies across the state to encourage competition, enforced a 10 percent decrease in energy prices, and limited the ability of energy monopolies to increase rates on customers. Assembly Bill 1890 also required publicly traded utility companies in California, such as Pacific Gas and Electric (PG\&E), to sell the majority of their generating capacity to independent producers, where it could be traded on the wholesale market.

The problem with deregulated energy markets is that they rely on an assumption of endless cheap energy and historical data on weather patterns to forecast demand. They are ill-equipped to handle changes in weather patterns produced by climatic shifts.

For decades, California has obtained at least a quarter of its energy from neighboring states despite the assumption of abundance in its wholesale markets. A significant portion of this imported energy comes from hydroelectric dams in Oregon and Washington. In 2000, the Pacific Northwest was hit with a drought that limited the electrical capacity of their hydroelectric dams, which, in addition to the profitable but highly criminal activities of opportunistic companies such as Enron, resulted in PG\&E filing for bankruptcy in 2001.

The inability to increase rates on end users coupled with the loss of surplus energy from the Pacific Northwest during a season of high energy demand resulted in large revenue losses. To emerge from bankruptcy, PG\&E turned to the state, which in turn backtracked on its previous policies protecting households from the wholesale energy market and forced ratepayers to front the bill. A $\$ 2.50$ surcharge was added to bills to help pay for PG\&E's debt. This tactic of expropriation mirrors those used by financial markets to stave off economic crisis and is a hallmark of neoliberalism. With a new safety net in place, PG\&E was able to emerge from bankruptcy by 2004, but the surcharge used to bail out PG\&E remained intact nonetheless. This surcharge has now transformed into a disaster fund that the state of California intends to use to bail out its utilities in case they are liable for future fires. 
This brings us to the present, when PG\&E has yet again filed for bankruptcy due to climatic shifts. In 2017 and 2018, PG\&E power lines sparked both the Wine Fire and the Camp Fire in Northern California due to abnormally dry weather and the lasting impacts of a historic drought. The Camp Fire alone was the largest and deadliest wildfire in many generations; nineteen thousand homes were destroyed, over two thousand acres were burned, and eighty-five people died. Each of these fires could have been prevented had PG\&E updated its power lines (some of which are one hundred years old) to be safer in dry weather. A recent article in the Wall Street Journal details that PG\&E had been aware of the risk of its outdated power lines for decades, yet the company found it more financially viable to postpone safety updates. The secret of the neoliberal scam of a profitable wholesale market for energy supposedly without higher retail rates was exposed; necessary maintenance for safety was abandoned in the interest of profit.

In addition to destroying the livelihoods of thousands, these fires have become a nightmare for one of neoliberalism's most coveted markets-insurance. The recent wildfires in California have cost insurance companies an estimated $\$ 24$ billion. ${ }^{8}$ In response to escalating concerns, insurance companies have raised premiums and, in some instances, refused to renew customers. Insurers are also holding PG\&E responsible for their large payouts to customers, forcing PG\&E into bankruptcy. This has become a financial opportunity for hedge funds, which have bought insurance claims in an effort to profit from PG\&E's mounting debt. Hedge funds such as Elliott Corp. and Baupost are now vying for an opportunity to restructure PG\&E under chapter 11 bankruptcy laws.

In an effort to stave off further debt, PG\&E and other utility companies in California have resorted to shutting off power to over three million people during periods of abnormally high winds and dry weather. This type of weather is predicted to continue into the future due to climate crisis, alternating between heavy precipitation (a problem that will put water utilities in a bind) and droughts. ${ }^{9}$ Of course, PG\&E has shut off customers' electricity with little regard for vulnerable populations. People with disabilities and the elderly are especially vulnerable to blackouts, and blackouts in general have been associated with increased death rates. ${ }^{10}$ An outcome of this expropriation is the increasing social and political disposability of those who have been expropriated. The people who rely on energy to survive are being hurt at no fault of their own - they are simply living their lives at the mercy of energy providers who see them as a source of capital rather than as human beings.

Energy systems in capitalist markets are predicated on ongoing processes of profit upon expropriation. In general, expropriation refers to 
forms of social, economic, and political domination unmediated by a wage contract and that function to support the exploitation of labor. ${ }^{11} \mathrm{To}$ understand this, we can look to how the majority of electricity consumed by individuals, even in wealthy nations, is used to reproduce basic needs. Heating, cooling, food storage, cleaning, and travel account for the majority of individuals' energy use. Most people rely on external sources of energy to meet these needs and lack the knowledge to reproduce these amenities without energy available on demand. This creates a power imbalance between energy consumers and energy providers that helps subordinate the interests of labor to the needs of capital.

Originally, fossil fuel-based energy was a form of resource expropriation that supported the exploitation of labor. This form of expropriation expedited the exploitation of workers by increasing the efficiency of both reproductive and productive labor. Electricity allowed laborers to produce goods more cheaply and to do it for longer periods of time than could have ever been imagined before fossil fuels were incorporated into the production chain. It also cut down the amount of time needed to perform reproductive labor, not least by increasing the efficiency of cooking and cleaning. As if that were not enough, electrification provided a new way for energy producers to profit from reproductive labor. Namely, the introduction of electricity made reproductive labor more dependent on electronic household appliances. Wholesale energy trading expands on the original model of energy expropriation by turning the individual's basic needs (such as the demand for energy) into a speculative market.

With all this in mind, it seems pertinent to ask: How long can neoliberalism withstand climate crisis and what are the consequences of continually supporting the neoliberal model? Let us start with the latter part of this question by noting three such consequences. First, the attempt to combat climate change through the wholesale energy market in Chile threatened to exacerbate preexisting inequality. Secondly, renewable energy consumption worldwide has fared better at mitigating emissions when it expands inequality. ${ }^{12}$ Lastly, it is clear that the people of Chile have had enough with widening inequality and took to the streets in protest, as have others around the globe, such as the Yellow Vests in France.

The energy cost hike was intended to protect the market from the volatility of renewable electricity systems. Through this volatility, renewable sources of energy such as wind and solar threaten the viability of the wholesale-energy-for-profit model. To put it differently, these energy sources are subject to ecology, not the market. The large fluctuation in energy supply, characteristic of highly intermittent sources (for example, renewables), make it difficult to profit from demand. Recall that this 
was what the wholesale market system was largely crafted to do. Nevertheless, this is a market problem, not a practical issue. Fossil fuels can easily become a backstop energy source for consumption during periods of low renewable supply or moments of peak usage when demand outstrips supply (while this is done to some degree now, it still occurs under the wholesale model). However, this would require the transformation of an energy system predicated on expropriation into one predicated on appropriation. By appropriation we mean energy production that is free from the alienation embedded in commodities. As a commodity, energy's value derives from unequal exchange, specifically, individuals pay more for energy than it costs to produce it. This form of unequal exchange is maintained through private ownership of distribution infrastructures, which limits the agency of households by creating an intermediary between the production and appropriation (that is, consumption) of energy. In this case, the intermediary is the wholesale energy market, which sets prices and determines what type of energy is used and when. To appropriate energy is to use it when it is useful to the individual, unmediated by unequal exchange, embedded in and limited by ecological cycles and thus free from alienation that derives from market pricing.

If peoples' agency were constrained by ecology and not the market, they could easily choose to perform energy-intensive tasks - such as traveling, cooking, cleaning, and charging batteries - during the peak hours of renewable energy supply and reduce their energy consumption during hours of low renewable supply. Under this model, individuals would respond to changes in weather patterns to reduce their impact on the climate without a market determining costs to generate greater profits.

While giving people the choice to live within the parameters of the earth's ecology seems like a fantasy, this is exactly what PG\&E is forcing people to do during fire season in California. The only difference is that PG\&E is making this decision for people. And they are doing it to reduce the likelihood that they will be implicated in and financially responsible for any future fires. Dry weather poses a danger for PG\&E because it has continually refused to adapt its infrastructure to the changing climate. Even without weather patterns altering due to anthropogenic climate change, dry weather is a possibility - and an inevitability - that should be addressed when building energy infrastructures. Failing to do so poses a danger to life and the greater social good. In truth, we are rather lucky it has only recently become a problem. Ultimately though, the increasing frequency of dry weather brought about by climate crisis has forced the issue by posing a threat to PG\&E's profits, and in doing so climate change has brought the financial solvency of the largest private utility 
firm in the nation into question. To protect the future of PG\&E, the state of California has created a fund that will insulate the behemoth from the insurance claims of the public. This is the neoliberal model of energy production: externalize costs and internalize surplus. It is a model that turns human beings into disposable objects; objects whose energy needs are determined by what is profitable and not what is hospitable or necessary to survival. Subjecting these energy sources to the faulty logic of an expropriative market rather than building systems that reflect the ecology is what people protested in Chile and are enduring in California. So, how long can neoliberalism withstand climate crisis? As long as we accept ourselves as disposable and firms like PGEE as essential, and not a moment more.

\section{Notes}

1. Andreas Malm, Fossil Capital (New 6. "Chile's Largest Metro Network to Be Twenty-First-Century California," Nature York: Verso, 2016); Simon Pirani, Burn- Powered by Solar and Wind," Climate Climate Change 8 (2018): 427-33. ing Up (Chicago: University of Chicago Action, June 21, 2017. Press, 2018).

7. "Chile's President Inks Bill to Cut Bell, "Lights Out: Impact of the August 2. Alexander Sammon, "Could Califor- Electricity Costs Amid Unrest," Xinhua, 2003 Power Outage on Mortality in nia Take Public Ownership of PG\&E?," October 26, 2019; Rachelle Krygier, New York, NY," Epidemiology 23, no. 2 Pacific Standard, February 7, 2019.

3. Lewis H. Divguid, "Exxon Buys Mine in Chile," Washington Post, January 25, 1978. "Chile's Protesters Got a Subway Fare (2012): 189-93.

4. John Authers, "Chile's Violence Has a Worrisome Message for the World," Bloomberg, October 23, 2019.

5. Felicia Jackson, "Chile's Cheap Power-Sign of a Solar Future?," Forbes, June 5,2019. Hike Reversed. Now They Want a New 11. John Bellamy Foster and Brett Political System," Washington Post, Oc- Clark, "The Expropriation of Nature," tober 30, 2019. Clark, "The Expropriation of Nature,"
Monthly Review 69, no. 10 (March 8. Matt Wirz and Juliet Chung, "PG\&E 2018): 1-27.

Trade Punishes Hedge Funds as California Burns," Wall Street Journal, October 30, 2019.

12. Julius Alexander McGee and Patrick Trent Greiner, "Renewable Energy Injustice: The Socio-Environmental Implica9. Daniel L. Swain, Baird Langenbrun- tions of Renewable Energy Consumpner, J. David Neelin, and Alex Hall, tion," Energy Research \& Social Science "Increasing Precipitation Volatility in 56(2019). 